hypoplasia caused by a decrease in the transverse size of the ventricle is of secondary importance.

Narrowing of the aorta in which the ratio of the diameter of the isthmus to the diameter of the ascending aorta is less than 0.53 and the ratio of the diameter of the descending aorta to the diameter of the ascending aorta is less than 0.6 [5] would alarm US doctors.

In our opinion, the causes of overdiagnosis of a potential defect were: firstly, wariness regarding the "criticality" during the neonatal period and borderline values of the above indices. Secondly, when assessing in the third trimester, an error rate in favor of the defect prevailed in fetuses of the size of an open oval window at the lower border of the gestational norm. Therefore, the increased blood flow through the Batalov duct led to a relative prevalence of its size over the aortic isthmus. Thirdly, visualization of the aortic arch showed different features at different gestational periods [4].

Conclusions. The work presented shows the importance of and nuances in the prenatal diagnosis of coarctation of the aorta, requiring not only theoretical knowledge but also practical skills. The difficulty of prenatal diagnosis is in the lack of patterns similar to newborns, and the final diagnosis depends largely on the experience of a specialist. Nevertheless, the above ultrasound criteria and indices make it possible to verify aortic coarctation in the fetus with a high degree of probability.

Disclosures:

The authors declare no conflict of interest.

References

1. Kailin J. A., Santos A. B., Furtun Y. B., Tejtel S. K., LantinHermoso R. Isolated coarctation of the aorta in the fetus: A diagnostic challenge. Echocardiography. 2017;34(12): 1768-1775. https://doi.org/10.1111/echo.13578

2. Gurvitz M., Burns K. M., Brindis R., Broberg C. S., Daniels C. J. [et al.] Emerging Research Directions in Adult Congenital Heart Disease: A Report From an NHLBI/ACHA Working Group. J. Am. Coll. Cardiol. 2016;67(16):19561964. https://doi.org/10.1016/j.jacc.2016.01.062

3. Satou G., Chang R. K., DeVore G. R., Abuel A., Sklansky M. Prenatal Sonographic Predictors of Neonatal Coarctation of the Aorta. J. Ultrasound Med. 2016;35(11):23532364. https://doi.org/10.7863/ultra.15.06049
4. Goudar S. P., Shah S. S., Shirali G. S. Echocardiography of coarctation of the aorta, aortic arch hypoplasia, and arch interruption: strategies for evaluation of the aortic arch. Cardiol. Young. 2016;26(8):1553-1562. https://doi.org/10.1017/S1047951116001670

5. Al Akhfash A. A., Almesned A. A., Al Harbi B. F. Al Ghamdi A., Hasson M. [et al.] Two-dimensional echocardiographic predictors of coarctation of the aorta. Cardiol. Young. 2015;25(1):87-94.

https://doi.org/10.1017/S1047951113001790

\footnotetext{
About authors:

Dyuzhikov Alexander Akimovich, MD, Professor, Honored Doctor of the Russian Federation, Director of the Cardiac Surgery Center; tel.: +79185581802; e-mail: duzhikov@aaanet.ru

Dyuzhikova Anastasia Vladimirovna, CMSc, Doctor of the Ultrasound Surgery Department; Assistant of the Department of ultrasound diagnostics; tel.: +79185078359; e-mail: dyuzhikova.a@bk.ru

Zhivova Larisa Valentinovna, Pediatric Cardiologist, Chief Freelance Specialist; tel.: +79043400042; e-mail: Arp64@mail.ru Likhachev-Mishchenko Oleg Valerievich, Cardiovascular Surgeon, Functional Diagnostics Specialist, Head of Innovation Department; tel.: +79289577609; e-mail: gelo2007@bk.ru
}

(c) Group of authors, 2019

UDC 616.151.4:616.36-006.6:615.322]-092.9

DOI - https://doi.org/10.14300/mnnc.2019.14134

ISSN - 2073-8137

\title{
THE INFLUENCE OF PLANT EXTRACTS ON THE VISCOSITY OF BLOOD AND THE OXIDATIVE STATUS OF ANIMALS WITH EXPERIMENTAL LIVER CANCER
}

\author{
Afanaseva G. A., Polukonova N. V., Avramets O. A., Ivlichev A. V., Dmitrienko E. A.
}

Saratov State Medical University named after V. I. Razumovsky, Russian Federation

\section{ВАИЯНИЕ РАСТИТЕАЬНЫХ ЭКСТРАКТОВ НА ВЯЗКОСТЬ КРОВИ И ОКСИААТИВНЫЙ СТАТУС ЖИВОТНЫХ С ЭКСПЕРИМЕНТААЬНЫМ РАКОМ ПЕЧЕНИ}

\author{
Г. А. Афанасьева, Н. В. Полуконова, О. А. Аврамец, А. В. Ивличев, Е. А. Амитриенко
}

\section{Саратовский госуАарственный меАицинский университет им. В. И. Разумовского, Российская ФеАерация}

The use of extracts of Chamaenerion angustifolium and Aristolochia clematitis improved the rheological properties of blood at high shear rates and decreased the content of intermediate lipoperoxidation products in experimental PC- 1 liver cancer in white rats. Extracts of Filipendula ulmaria and Petasites spurius showed no effect on either endpoint. 
Использование экстрактов кипрея узколистного (Chamaenérion angustifolium) и кирказона ломоносовидного (Aristolóchia clematítis) улучшало реологические свойства крови на высоких скоростях сдвига и снижало содержание промежуточных продуктов липопероксидации при экспериментальном раке печени РС-1 у белых крыс. У экстрактов таволги вязолистной (Filipendula ulmaria) и белокопытника войлочного (Petasítes spúrius) указанных эффектов не обнаружено.

Ключевые слова: биофлавоноиды, липопероксидация, вязкость крови, канцерогенез

For citation: Afanaseva G. A., Polukonova N. V., Avramets O. A., Ivlichev A. V., Dmitrienko E. A. THE INFLUENCE OF PLANT EXTRACTS ON THE VISCOSITY OF BLOOD AND THE OXIDATIVE STATUS OF ANIMALS WITH EXPERIMENTAL LIVER CANCER. Medical News of North Caucasus. 2019;14(3):539-541. DOI - https://doi.org/10.14300/mnnc.2019.14134

Для цитирования: Афанасьева Г. А., Полуконова Н. В., Аврамец О. А., Ивличев А. В., Дмитриенко Е. А. ВлИЯНИЕ РАСТИТЕЛЬНЫХ ЭКСТРАКТОВ НА ВЯЗКОСТЬ КРОВИ И ОКСИДАТИВНЫЙ СТАТУС ЖИВОТНЫХ С ЭКСПЕРИМЕНТАЛЬНЫМ РАКОМ ПЕЧЕНИ. Медицинский вестник Северного Кавказа. 2019;14(3):539-541.

DOI - https://doi.org/10.14300/mnnc.2019.14134

GPL - lipid hydroperoxides

LPO - lipid peroxidation products

MSM - medium-weight molecules

$\mathrm{T}$ umor transformation is accompanied by paraneoplastic changes in the blood coagulation potential, plasma protein composition, and quantitative and qualitative characteristics of the formed elements of peripheral blood. Accordingly, changes in the regional blood flow and microcirculation result, which are caused by shifts in the cytokine status and excessive accumulation of lipid peroxidation products (LPO) during damage to cell membranes $[1,2]$.

The use of antioxidants can increase the oxidative stability of biological membranes while maintaining their functional activity because of the inhibition of LPO [3, 4]. Selected bioflavonoids whose antioxidant activities are associated with the presence of their carbonyl and hydroxyl groups remain promising for experimental studies of their biological potential. However, along with their antioxidant effects, a number of flavonoids can contribute to the formation of cytotoxic radicals and hydrogen peroxide, and thus exhibit pro-oxidant effects [5]. In this regard, the study of the effects of plant extracts containing flavonoids is an urgent task.

The aim of this work was to study the effect of extracts of various plants on the blood viscosity and oxidative status of white rats with experimental PC-1 liver cancer.

Material and Methods. The experiments were carried out in accordance with international ethical standards and principles for conducting biomedical research (Strasbourg, 1986; International Guiding Principles for Biomedical Research Involving Animals, 2012).

A tumor suspension of liver alveolar PC-1 cancer cells obtained from a bank of tumor strains at the National Medical Research Center of Oncology named after N. Blokhin was prepared in a solution of Hanks balanced salt solution. To simulate the tumor process, a $25 \%$ suspension of tumor cells in a volume of $0.5 \mathrm{~mL}$ was injected under the thigh skin of male outbred white rats.

Male white rats weighing 130 to $160 \mathrm{~g}$ were divided into six groups of 10 animals each. The control group consisted of intact animals that were injected intramuscularly with saline (group 1). The comparison group consisted of animals with an inoculated tumor that was intramuscularly injected with physiological solution (group 2). The treatment groups consisted of rats with an inoculated tumor dosed with extracts from cyprus narrow-leaved fireweed (Chamaenerion angustifolium), felon butterbur (Petasites spurius), European birthwort
(Aristolochia clematitis) and meadowsweet (Filipendula ulmaria) at $110 \mathrm{mg} / \mathrm{kg}$ for 1 day and then $1 \mathrm{mg} / \mathrm{kg}$ once a day intramuscularly (groups 3, 4, 5, and 6, respectively). The introduction of extracts or physiological saline was started 7 days after implantation of the tumor suspension.

The blood rheological properties were studied using an ARP-2 apparatus (Tomsk, Russia) at shear rates from 5 to $300 \mathrm{~s}^{-1}$. The content of lipid hydroperoxides (HPL) and medium-weight molecules (MWM) in the blood serum was studied by spectrophotometric methods [9].

Statistical processing was performed using STATISTICA 6.0 software (StatSoft Inc., USA). To analyze the type of distribution, the Shapiro - Wilk test was used. The characterization of the center of the grouping of values of a random variable was carried out using a median with an interquartile range (25th and 75th percentiles). Samples were compared using the Mann Whitney test [8].

Results and Discussion. The assessment of the rheological properties of the blood was carried out on the 28th day of the experiment at shear rates of 5,10 , $20,50,100,150,200$, and $300 \mathrm{~s}^{-1}$, which allowed the determination of the blood viscosity in various parts of the vascular bed.

In animals with transplanted PC-1 liver cancer, an increase in blood viscosity was found at shear rates of 10 , $20,50,100,150,200$, and $300 \mathrm{~s}^{-1}\left(\mathrm{p} 10-300 \mathrm{~s}^{-1}<0.01\right)$ compared with the control group, which indicated a change in the rheological properties of the blood under various flow conditions. The accumulation of $\mathrm{HPL}$ in the blood serum $(p<0.001)$ and MWM $(p<0.001)$ was observed compared with the same indicators of intact animals and confirmed the development of auto-toxicity in the tumor process.

After the introduction of aqueous solutions of the extracts of cyprus narrow-leaved fireweed and European birthwort to animals with transplanted PC-1 liver cancer, a decrease in blood viscosity was noted at shear rates from 50 to $300 \mathrm{~s}^{-1}\left(\mathrm{p} 50-300 \mathrm{~s}^{-1}<0.05\right)$ compared with the animals with an inoculated tumor that were not exposed to the extract. The levels of HPL and MWM were significantly lower $(p<0.001)$ when animals were treated with these extracts (groups 3 and 5), but not when treated with physiological saline, which may indicate the formation of an antioxidant effect.

When the extracts of butterbur and meadowsweet were administered to rats with transplanted PC-1 liver cancer, no significant differences in the rheological 
properties of blood at any shear rates were observed compared with the parameters of the comparison group. The levels of HPL and MWM in the blood of these treated animals remained high relative to the corresponding indices of the intact group and were comparable to the comparison group.

Conclusions. The results obtained may indicate a pathogenetic relationship between the intensification of free radical oxidation of lipids and a violation of the viscosity properties of blood in experimental PC-1 alveolar liver cancer. The introduction of extracts of narrow-leaved fireweed and European birthwort to white rats with transplanted PC-1 liver cancer corrected violations of the rheological properties of blood at high shear rates and manifested antioxidant properties.

\title{
Disclosures:
}

The authors declare no conflict of interest.

Acknowledgment:

We thank Renee Mosi, PhD, from Edanz Group (www.edanzediting.com/ac) for editing a draft of this manuscript.

\section{References}

1. Bizzarri M., Cucina A. Tumor and the microenvironment: A chance to reframe the paradigm of carcinogenesis? BioMed Research International. 2014;2014:934038. https://doi.org/10.1155/2014/934038

2. Bower J. E., Lamkin D. M. Inflammation and cancer-related fatigue: Mechanisms, contributing factors, and treatment implications. Brain, Behavior, and Immunity. 2013;30(Suppl.):S48-S57. https://doi.org/10.1016/j.bbi.2012.06.011

3. Agati G., Azzarello E., Pollastri S., Tattini M. Flavonoids as antioxidants in plants: location and functional significance. Plant Sci. 2012:196:67-76.

https://doi.org/10.1016/j.plantsci.2012.07.014
4. Liu X.-M., Liu Y.-J., Huang Y., Yu H.-J., Yuan S. [et al.] Dietary total flavonoids intake and risk of mortality from all causes and cardiovascular disease in the general population: A systematic review and meta-analysis of cohort studies. MolecularNutrition and Food Research. 2017;61(6):art. no.1601003. https://doi.org/10.1002/mnfr.201601003

5. Durnova N. A., Afanas'eva G. A., Kurchatova M. N. Content of Oxidative Stress Markers in Blood Plasma under the Action of Extracts of Gratiola officinalis L.. Helichrysum arenarium (L.) Moench, and Anthocyanin Forms of Zea mays L. Eksperimentalnaya i klinicheskaya farmacologiya. - Experimental and clinical pharmacology. 2015;78(7):36-40. https://doi.org/10.30906/0869-2092-2015-78-7-36-40

\section{About authors:}

Afanaseva Galina Aleksandrovna, MD, PhD, Professor, Head of the Department of pathological physiology named after academician A. A. Bogomolets; tel.: +78452669768; e-mail: gafanaseva@yandex.ru

Polukonova Natalia Vladimirovna, DBSi, Professor, Professor of the Department of general biology, pharmacognosy and botany, Head of the Laboratory of cellular technologies; tel.: +79603446347; e-mail: polukonovanv@yandex.ru Avramets Olga Alexandrovna, student; tel.: +79873587659; e-mail: olga-chaos-1@yandex.ru

Ivlichev Alexey Vasilievich, teacher of the Department of pathological physiology named after academician A. A. Bogomolets; tel.: +79873277619; e-mail: alexivli4ev@yandex.ru

Dmitrienko Ekaterina Aleksandrovna, student; tel.: +79372698848; e-mail: katya-13-97@mail.ru.

TRANS-SCROTAL ORCHIECTOMY IN LOCALIZED YOLK SAC TESTICULAR TUMORS IN CHILD. HOW IS IT SAFE?

\author{
Omar Abdulwahed Mazen Sallom Firas Diab Sef Din Sultan
}

Damascus hospital, Syria

\section{ЧРЕЗМОШОНОЧНАЯ ОРХИАЭКТОМИЯ У РЕБЕНКА С АОКААИЗОВАННОЙ ОПУХОАЬЮ ЯИЧКА, ИСХОАЯЩЕЙ ИЗ ЖЕАТОЧНОГО МЕШКА. НАСКОАЬКО ЭТО БЕЗОПАСНО?}

\author{
О. Абаулвахен
}

\section{Аамасская больница, Сирия}

Testicular tumors in children are rare, founding only $1 \%$ of all pediatric solid tumors. We report a case of 14 months old child, who was referred to us for recent scrotal painless tumefaction. The clinical examination with the US confirmed the testicular involvement of this tumor. An abnormally elevated blood level of the $\alpha$-fetoprotein was decisional for the embryonic origin of this tumor. A trans-scrotal approach realized a radical orchiectomy in the bloc with a high ligation-section of the spermatic cord. The histopathology examination of this tumor has shown a yolk sac tumor. The $\alpha$-fetoprotein was normalized 